\title{
IMPLEMENTATION OF INDONESIAN LEARNING STORY SKILL OF CARTOON PUPPET MEDIA OF STUDENT OF GRADE IV OF STATE PRIMARY SCHOOL
}

\author{
Vivi Rulviana \\ rulvianavivi@ikippgrimadiun.ac.id \\ IKIP PGRI MADIUN
}

\begin{abstract}
The objective of this research is to investigate the planning and implementation telling skill the use of cartoon puppet media of the student in Grade IV of State Primary School of Tladan 2, Kawedanan, Magetan.This research used the qualitative research method. The source of this research were Principal, Class Teacher of Grade IV, and the students in Grade IV by using interview, and observation. They were analyzed by using the interactive model of analysis comprising data reduction, data display, and conclusion drawing of verification.The results of research are as follows: 1) the planning of telling by teacher with preparing the annual program, the semester program, the details of effective weeks, the journal of teaching, lesson plan, syllabus development and the development of assessment systems, 2) Implementation of the learning skills of telling is packed with a variety of methods and media puppet cartoon. Teachers began teaching with fun activities for the creation of learning readiness, motivation and interest in learning in students. Teachers utilized cartoon puppet media in learning storytelling in the fourth grade to get a great result for students for example: interested in learning, motivation, self-confidence and have the ability to tell a coherent accordance with the storyline.
\end{abstract}

Keywords: learning, telling skill, and cartoon puppet media

\begin{abstract}
Abstrak
Tujuan penelitian ini adalah untuk mengetahui perencanaan dan pelaksanaan pembelajaran bercerita dengan menggunakan media wayang kartun pada siswa kelas IV Sekolah Dasar Negeri Tladan 2, Kawedanan, Magetan.Penelitian ini merupakan penelitian kualitatif yang dilakukan di SDN Tladan 2, Kawedanan, Magetan.Narasumber dalam penelitian ini adalah kepala sekolah, guru kelas IV, dan siswa kelas IV. Teknik pengumpulan data menggunakan dokumentasi, wawancara, dan observasi. Analisis data yang dilakukan dengan reduksi data, sajian data, serta penarikan simpulan dan verifikasi.Hasil penelitian menunjukkan bahwa 1) perencanaan pembelajaran yang dilakukan oleh guru dengan mempersiapkan program tahunan, program semester, rincian minggu efektif, jurnal mengajar, rencana pelaksanaan pembelajaran, pengembangan silabus dan pengembangan sistem penilaian, 2) Pelaksanaan pembelajaran keterampilan bercerita dikemas dengan berbagai metode dan media wayang kartun. Guru memulai pembelajaran dengan kegiatan yang menyenangkan untuk mencipatakan kesiapan belajar, motivasi dan minat belajar pada siswa. Guru memanfaatkan media wayang kartun dalam pembelajaran bercerita di kelas IV tersebut mendapatkan hasil yang sangat memuaskan dimana siswa memiliki minat, motivasi, percaya diri serta memiliki kemampuan bercerita secara runtut sesuai dengan alur cerita.
\end{abstract}

Kata Kunci: pembelajaran, keterampilan bercerita, media wayang kartun 


\section{A. PENDAHULUAN}

Pendidikan memiliki peranan penting dalam menciptakan dan menentukan kualitas seseorang. Kemajuan bangsa dan negara ditentukan oleh pemanfaatan sumber daya manusia yang berkualitas. Pendidikan yang diharapkan bukan sebatas pemberian atau pentransferan ilmu dari pengajar kepada peserta didik saja, tetapi pendidikan yang mampu mengantarkan peserta didik menjadi pribadi yang unggul dan dapat menghadapi kehidupannya di masa yang akan datang secara cerdas, kreatif dan mandiri. Pendidikan yang bermutu diperlukan untuk menciptakan peserta didik yang unggul. Adapun pendidikan yang bermutu harus mencakup dua dimensi yaitu orientasi akademis dan orientasi keterampilan hidup yang esensial. Berorientasi akademik berarti menjanjikan prestasi akademik peserta didik sebagai tolak ukurnya, sedangkan berorientasi keterampilan hidup (life skill) yang esensial adalah pendidikan yang dapat membuat peserta didik dapat bertahan (survive) di kehidupan nyata (Depdiknas, 2007:
2). Keterampilan berbahasa dalam mata pelajaran bahasa Indonesia mempunyai empat komponen, yaitu keterampilanmenyimak (listening skills), keterampilan berbicara (speaking skills), keterampilan membaca (reading skills), dan keterampilan menulis (writing skills) (Henry, 2008:1).

Perkembangan di zaman berkembang ini mengharuskan suatu instansi pendidikan dapat menciptakan lulusan yang memiliki keahlian-keahlian, salah satunya kemampuan keterampilan berbicara. Pembelajaran berkenaan dengan keterampilan berbicara merupakan salah satu bagian dari pendidikan yang memiliki peranan yang penting dan strategis dalam proses komunikasi di tengah-tengah pergaulan dan interaksi sosial. Seseorang akan mampu berkomunikasi dengan pihak lain sesuai konteks dan situasinya melalui penguasaan berbicara yang baik dan benar. Salah satu upaya untuk dapat membangkitkan kemampuan berbicara pada siswa yaitu dengan 
mengajarkan keterampilan bercerita yang termasuk dari bagian keterampilan berbicara. Pembelajaran keterampilan bercerita di Sekolah Dasar (SD) adalah pembelajaran yang mengarah kepada upaya pembinaan kemampuan siswa untuk memiliki kemampuan berbicara yang baik dan benar, baik secara lisan maupun tulis dalam berbagai keperluannya.

Keberhasilan pembelajaran bercerita di kelas IV Sekolah Dasar (SD) Negeri Tladan 2 Kawedanan, Magetan tersebut ditentukan berdasarkan peran serta pendidik di dalam memanfaatan media pembelajaran berupa wayang kartun yang tentunya menarik dan mampu menggugah minat belajar siswa dan melatih siswa untuk terampil bercerita. Pembelajaran merupakan suatu alat yang dapat membantu proses belajar mengajar dan berfungsi untuk memperjelas makna pesan yang disampaikan, sehingga dapat mencapai tujuan pembelajaran (Azhar, 2011: 9). Media pembelajaran adalah sarana untuk meningkatkan kegiatan proses belajarmengajar. Pembelajaran dengan memanfaatkan media pembelajaran tentunya memiliki banyak manfaat/keuntungan. Suwarna (2002: 145) menyebutkan keuntungan dari menggunakan mediapembelajaran yaitu: a) menarik perhatian siswa, b) menambah minat belajar siswa, c) mempermudah dan memperjelas materi pelajaran, d) meringankan tugas guru atau pengajar, e) merangsang daya kreasi, dan f) membuat pembelajaran menjadi tidak membosankan dan monoton. Penelitian ini bertujuan untuk mendeskripsikan perencanaan, pelaksanaan, keterampilan bercerita pada Pembelajaran Keterampilan Bercerita Bahasa Indonesia Dengan Media Wayang Kartun Kelas IV di Sekolah Dasar Negeri Tladan 2 Kawedanan, Magetan.

\section{B. METODE PENELITIAN}

Penelitian ini dilaksanakan di Sekolah Dasar Negeri Tladan 2 yang beralamat di jalan raya Gorang Gareng - Lembeyan, Desa Tladan, Kecamatan Kawedanan, Kabupaten Magetan. Jenis penelitian yang digunakan adalah penelitian kualitatif. Penelitian yang bersifat kualitatif deskriptif yaitu metode penelitian yang mengarahkan untuk 
64 | Premiere Educandum, Volume 6 Nomor 1, Juni 2016, 61 - 71

mendeskripsikan, mencatat, analisis, dan menginterpretasikan kondisi yang terjadi untuk memperoleh informasi mengenai suatu keadaan.

Penelitian yang dilakukan ini merupakan penelitian kualitatif yang menggunakan metode penelitian bersifat kualitatif deskriptif, yaitu metode penelitian yang mengarahkan untuk mencapai tujuan yang telah ditentukan karena didalamnya terdapat upaya mendeskripsikan, mencatat, analisis dan menginterpretasikan kodisi-kondisi yang sekarang terjadi serta bertujuan untuk memperoleh informasiinformasi mengenai keadaan saat ini, dan melihat kaitan antara variabelvariabel yang ada (Mardalis, 2003: 26).

Dalam penelitian kualitatif tentunya tidak terlepas dari peranan sumber data. Sumber data merupakan bagian yang sangat penting karena ketepatan memilih dan menentukan jenis sumber data akan menentukan ketepatan dan kedalaman informasi yang diperoleh. Sumber data penelitian ini adalah informan, peristiwa serta tempat/lokasi dengan teknik pengumpulan data menggunakan dokumentasi tertulis atau arsip, wawancara, serta observasi. Data yang dibutuhkan apabila sudah diperoleh, data-data tersebut dianalisis menggunakan metode deskriptif kualitatif untuk menjawab permasalahan yang ada dalam rumusan masalah. Dengan demikian data tersebut akan dijadikan sebagai bahan pendukung untuk menjawab rumusan masalah yang ada. Karena penelitian ini bersifat lentur dan terbuka, data yang dikumpulkan dianalisis untuk memperoleh kesimpulan dengan langkah seperti yang digambarkan dalam gambar berikut (H. B. Sutopo, 2002:96)

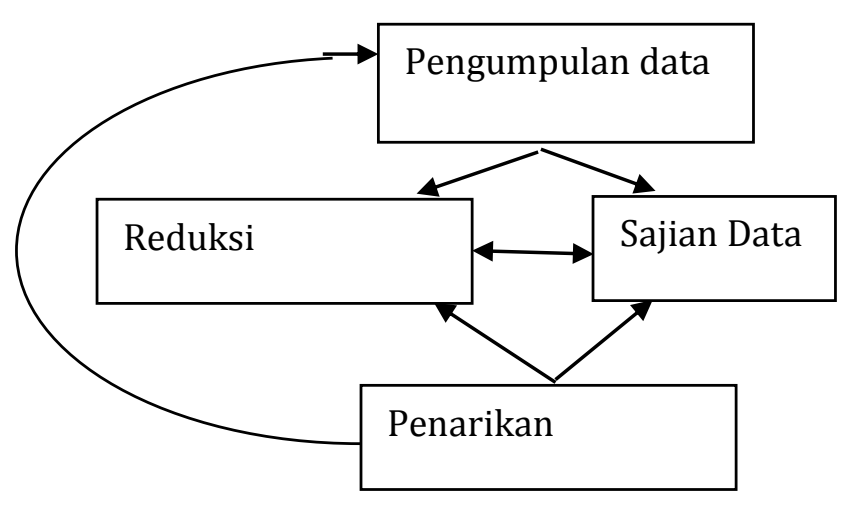

Gambar 1 Analisis Data

Dalam penelitian ini menggunakan teknik-teknik validitas data yaitu triagulasi sumber, triagulasi metode dan review informan. 


\section{HASIL PENELITIAN DAN PEMBAHASAN}

1) Perencanaan Pembelajaran BerceritaDengan Media Wayang Kartun Kelas IV di Sekolah Dasar Negeri Tladan 2 Kawedanan Magetan

Pembelajaran merupakan suatu proses interaksi antara siswa dan guru yang di dalamnya terdapat seperangkat sistem untuk mencapai tujuan pembelajaran yang telah ditetapkan.Menurut City, A. Elizabeth (2011:1) "Instructional is the relationship between the teacher, the student, and the content" (Pembelajaran adalah hubungan antara guru, siswa, dan konten). Dari pendapat tersebut dapat dikatakan bahwa pembelajaran tentunya tidak dapat berdiri sendiri. Harus ada beberapa komponen diantaranya guru, siswa dan materi yang akan disampaikan oleh guru/pengajar kepada siswa/pembelajar dengan melakukan interaksi belajar.

Dalam suatu pembelajaran sebelum adanya penerapan, suatu perencanaan memang sangat penting karena dapat mendukung dan menentukan keberhasilan kegiatan pembelajaranyang akan ditempuh tersebut. Persiapan yang dilakukan oleh guru dapat berupa program tahunan, program semester, rincian minggu efektif, jurnal mengajar, rencana pelaksanaan pembelajaran, pengembangan silabus dan pengembangan sistem penilaian. Rencana pembelajaran tersebut mencakup penerapan standar kompetensi, penerapan kompetensi dasar, media pembelajaran, langkahlangkah pembelajaran, dan sistem evaluasi atau penilaian.

Perencanaan pembelajaran selain sebagai perangkat mengajar juga sebagai pedoman atau panduan guru dalam mengajar, sebelum menerapkan pembelajaran guru harus menyesuaikan perencanaan pembelajaran dengan kondisi siswa. Strategi pembelajaran dilaksanakan sesuai dengan yang telah tercantum dan dirancang dalam rencana pelaksanaan pembelajaran. Iskandarwassid dan Dadang Sunendar (2009:9) menjelaskan bahwa strategi pembelajaran meliputi kegiatan atau pemakaian teknik yang dilakukan oleh pengajar mulai dari perencanaan, pelaksanaan kegiatan sampai ketahap 
66 | Premiere Educandum, Volume 6 Nomor 1, Juni 2016, 61 - 71

evaluasi, serta program tindak lanjut yang berlangsung dalam situasi edukatif untuk mencapai tujuan tertentu, yaitu pengajaran.

Guru menerapkan dengan runtut rencana pembelajaran yang telah dibuat proses pembelajaran. Tahap-tahap proses pembelajaran sesuai dengan yang tertulis pada rencana pembelajaran. Guru selalu memberikan apersepsi kepada siswa sebelum kegiatan belajar mengajar berlangsung. Hal ini dilakukan sebagai pemberi motivasi dan pembangkit semangat dalam belajar. Guru juga menjelaskan tujuan dari pembelajaran yang akan dicapai sehingga siswa mengerti kemana arah kegiatan pembelajaran.

2) Pelaksanaan Pembelajaran Bercerita Dengan Media Wayang Kartun Kelas IV di Sekolah Dasar Negeri Tladan 2 Kawedanan Magetan Pelaksanaan kegiatan pembelajaran adalah upaya yang dilakukan oleh guru untuk merealisasikan rancangan yang telah disusun baik dalam silabus maupun rencana pembelajaran. Pelaksanaan kegiatan pembelajaran menunjukkan penerapan langkah-langkah suatu strategi pembelajaran yang ditempuh oleh guru untuk menyediakan pengalaman pembelajaran (Wina Sanjaya, 2009:29). Pembelajaran merupakan proses interkasi antara siswa dan guru dalam pendidikan. Hal tersebut sesuai dengan makna lain yaitu guru atau pendidik merupakan administrator dan fasilitator dalam proses pemerolehan ilmu dan pengetahuan, penguasaan tabiat, serta pembentukan sikap pada peserta didik.

Pengembangan program pembelajaran yang dilakukan antara siswa dan guru terlaksana dalam pendidikan formal yaitu sekolah. Peran guru sangatlah penting di dalam dunia pendidikan. Guru di pandang sebagai orang yang serba mengetahui, artinya guru dipandang sebagi orang yang paling pandai. Guru juga harus mempersiapkan tugas-tugas, memberikan latihan-latihan, dan menentukan peraturan serta meningkatkan kemajuan siswanya dalam kegiatan belajar mengajar.

Di sekolah siswa dengan berbagai karakteristik akan mendapatkan pelatihan dan 
pengalaman praktis.Hal tersebut

berdasarkan kesimpulan bahwa

mengajar merupakan aktifitas khusus

yang dilakukan guru untuk menolong

dan membimbing anak didik dalam

memperoleh perubahan dan pengembangan skill (keterampilan),

attitude (sikap), appreciation (penghargaan), dan knowledge (pengetahuan).

Perubahan yang dimaksud adalah perubahan pada diri siswa melalui proses kegiatan belajar mengajar dalam mengorganisasikan atau mengatur (mengelola) lingkungan agar tercipta suasana yang sebaik-baiknya dan menghubungkan dengan peserta didik sehingga terjadi proses belajar yang menyenangkan. Proses belajar mengajar akan menyenangkan apabila guru menggunakan suatu cara agar siswa termotivasi untuk belajar, salah satunya yaitu mengenai pemilihan media pembelajaran.

Bercerita merupakan salah satu keterampilan dalam mata pelajaran bahasa Indonesia. Ada orang yang memang mempunyai bakat untuk bercerita dan ada yang tidak memilikinya, namun persoalannya bukanlah terletak pada berbakat atau tidaknya seseorang dalam bercerita, tetapi berdasarkan kemauan untuk terus menerus berlatih.

Siswa agar lancar dalam menguasai keterampilan bercerita digunakanlah wayang kartun sebagai media untuk menarik minat dan motivasi belajar siswa karena di dalam pementasan wayang selain ada sebuah alur cerita dan cara-cara bercerita yang merupakan bagian dari bercerita. Wayang Kartun adalah alat peraga atau alat pembelajaran yang digunakan guru dalam menyampaikan materi dongeng yang digerakkan dengan tangan dan berbentuk gambar kartun. Wayang Kartun ini dibuat dari bahan kertas yang sesuai dengan tokoh binatang dalam dongeng. Levied an Lentz, kelebihan media Wayang Kartun sebagai media pembelajaran adalah mengarahkan siswa untuk berkomunikasi, menggugah emosi dan sikap siswa, memperlancar pencapaian tujuan untuk memahami dan mengingat informasi dan membantu memahami teks siswa yang lemah dalam membaca (Ngadino, 2009). Berdasarkan 
pengamatan yang dilakukan peneliti di kelas IV tersebut, dapat diketahui bahwa motivasi dan minat belajar siswa lebih meningkat sera keaktifan siswa di dalam kelas dan kemampuan bercerita siswa cukup baik, karena dengan adanya contoh dari guru dalam menjalankan cerita si wayang, siswa memiliki gambaran tentang cara bercerita dan siswa tersebut mampu bercerita sesuai alur.

Pelaksanaan pembelajaran terjadi interaksi aktif antara guru dan siswa sehingga kegiatan belajar mengajar di dalam kelas tercipta lebih menyenangkan dan tidak membosankan. Guru selalu membuat suasana pembelajaran yang lebih mengedepankan potensi yang dimiliki siswa. Selain itu guru juga berusaha membimbing dan memberikan pengarahan kepada siswa tentang bagaimana cara bercerita yang baik dan benar, sehingga siswapun mengakui bahwa hal tersebut sangat membantu dan memudahkan siswa dalam bercerita. Guru dengan tekun memberikan arahan dan gambaran bagaimana cara bercerita dengan baik, siswapun merasa terbantu dengan arahan yang diberikan oleh gurunya tersebut sehingga siswa mampu dengan baik bercerita di depan kelas dengan tingkat kepercaya dirian yang baik pula.

Guru berperan sangat penting dalam proses pembelajaran ini. Keberhasilan didalam pembelajaran ditentukan dari bagaimana guru tersebut mengajar. Guru mempunyai kebebasan untuk mengembangkan sistem penilaian terhadap anak didiknya. Evaluasi pembelajaran yang digunakan sesuai dengan kondisi guru, sekolah, dan siswa dalam memahami materi yang telah diajarkan.Sebagian besar siswa kelas IV menyukai materi tentang bercerita walaupun di antara mereka masih ada yang mengalami kendala dalam bercerita seperti kesulitan dalam merangkai kata sesuai alur cerita.

Hal ini dapat dilihat dari hasil penilaian yang dilakukan oleh guru dan peneliti. Pencapaian hasil kriteria ketuntasan minimal rata-rata nilai siswa sudah di atas KKM. Hal itu terlihat dari jumlah siswa yang terdiri atas 12 siswa, sebanyak 9 siswa atau sekitar 75\% dari jumlah siswa yang mendapat nilai di atas standart KKM 
dan 3 siswa atau 25\% mendapat nilai di bawah standart KKM, sehingga dapat disimpulkan bahwa siswa kelas IV mayoritas kemampuan dalam bercerita tergolong sudah baik. Adapun kesulitan yang kadang ditemui adalah dalam masalah penataan alur cerita, pelafalan, dan artikulasi, gerak dan mimik, intonasi, dan pemilihan kata yang tepat, akan tetapi kendala-kendala tersebut dapat diatasi dan diarahkan supaya menjadi lebih baik lagi oleh guru kelas ,dengan selalu memberikan bimbingan dan arahan kepada siswa tentang bagaimana cara bercerita dengan baik dan benar. Evaluasi yang dilakukan oleh guru dalam pembelajaran ini, salah satunya yaitu memberikan tugas kepada siswa untuk menceritakan kembali cerita wayang dengan media wayang kartun yang telah dibuat dan disediakan guru dihadapan guru dan teman-temannya sekelas dengan menggunakan bahasanya sendiri.

Dalam pembelajaran bercerita yang dilakukan oleh guru, yaitu dengan mengamati siswa dalam bercerita, apakah sudah sesuai atau belum dengan cara bercerita dengan baik dan benar serta memperhatikan pelafalan dan artikulasi, gerak dan mimik, intonasi, dan pemilihan kata yang tepat. Selain mengamati hasil pekerjaan siswa, guru juga melakukan penilaian secara menyeluruh yang meliputi aspek kognitif, afektif, dan psikomotorik siswa. Penilaian ini dilakukan pada saat proses belajar mengajar berlangsung sehingga guru dapat mengetahui perkembangan siswa dari awal hingga akhir pembelajaran.

\section{SIMPULAN DAN SARAN}

Berdasarkan hasil penelitian yang dilakukan tentang Pelaksanaan Pembelajaran Bercerita Bahasa Indonesia Kelas IV di SDN Tladan 2, Kecamatan Kawedanan, Magetan dapat disimpulkan sebagai berikut: 1) Kondisi pembelajaran bahasa Indonesia pada siswa kelas IV SDN Tladan 2, Kecamatan Kawedanan, Magetan, kegiatan belajar mengajar di kelas tersebut sudah berlangsung dengan baik, tertib, dan disiplin. Siswa-siswa tergolong aktif, rajin, dan patuh terhadap guru. Guru berusaha untuk menciptakan suasana pembelajaran yang aktif dan kondusif. Guru pun menyadari bahwa 
70 | Premiere Educandum, Volume 6 Nomor 1, Juni 2016, 61 - 71

siswa-siswanya harus dibantu untuk mengoptimalkan kemampuannya masing-masing, siswa-siswi pada umumnya antusias menerima pembelajaran yang diberikan oleh guru. Suasana pembelajaran cukup kondusif walaupun terkadang ada beberapa siswa yang kurang aktif dan ada yang kurang mempunyai keberanian pada saat diberi tugas bercerita di depan kelas namun hal itu dapat diatasi oleh guru. 2) Pelaksanaan pembelajaran bercerita dengan menggunakan media wayang kartun pada siswa kelas IV SDN Tladan 2, Kecamatan Kawedanan, Magetan, guru sudah mampu melaksanakan kegiatan pembelajaran bercerita dengan baik. Hal ini terlihat pada saat proses pembelajaran berlangsung, guru mampu membimbing dan membantu siswanya untuk memahami alur-alur cerita untuk selanjutnya di sampaikan atau diceritakan dengan baik oleh para siswa di depan kelas. Menggunakan media yang kreatif dalam pembelajaran dapat memberi atau menambah motivasi siswa agar lebih senang dan antusias dalam melakukan kegiatan belajar.
Berdasarkan analisis data di lapangan dapat dikemukakan saransaran sebagai berikut: 1) Pihak sekolah hendaknya mempertahankan pembelajaran keterampilan bercerita pada siswa agar bakat siswa tentang kegiatan bercerita dapat berkembang lagi serta prestasi yang diraih siswa lebih meningkat serta melengkapi sarana dan prasarana sekolah. 2) Untuk tenaga pendidik lebih kreatif dan inovatif agar siswa menjadi lebih aktif dan kreatif lagi. 3) Untuk siswa harus lebih semangat lagi dalam mengikuti kegiatan pembelajaran di kelas agar memperoleh hasil pembelajaran yang semaksimal mungkin serta mendapatkan prestasi yang lebih baik lagi dari tahun ke tahun.

\section{DAFTAR PUSTAKA}

Azhar Arsyad. 2011. Media Pembelajaran. Jakarta: PT Raja Grafindo Persada.

City, A. Elizabeth, Elmore. 2011. “ Instructional Rounds in Education", Journal of Education Technology. Vol 1 No 1, Pg: 1-5.

Depdiknas. 2007. Pedoman Penyelenggaraan Pendidikan Untuk Peserta Didik Berkecerdasan Istimewa (Program Akselerasi). Jakarta: 
Direktorat Jenderal Manajemen

Pendidikan Dasar dan

Menengah Direktorat

Pembinaan Sekolah Luar Biasa.

H.B. Sutopo. 2002. Metodologi Penelitian Kualitatif. Surakarta: Universitas Sebelas Maret.

Henry Guntur Tarigan. 2008. Berbicara sebagai Suatu

Ketrampilan

Berbahasa.Bandung :Angkasa.

Iskandarwassid dan Dadang

Sunendar. 2009.

StrategiPembelajaranBahasa.

Bandung: PT Remaja

Rosdakarya.

Madarlis. 2003. Metode Penelitian. Jakarta: PT Bumi Aksara.

Ngadino, Y. (2009). Pengembangan Media Pembelajaran. Surakarta: Pendidikan Profesi Guru FKIP UNS.

Suwarna Pringgawidagda. (2002). Strategi Penguasaan Berbahasa. Yogyakarta:Adicita Karya Nusa.

Wina Sanjaya. 2009. Perencanaan dan Desain Sistem Pembelajaran. Jakarta: Kencana Prenada Media. 